\title{
Collectors endanger Australia's most threatened snake, the broad- headed snake Hoplocephalus bungaroides
}

\author{
Jonathan K. Webb, Barry W. Brook and Richard Shine
}

\begin{abstract}
The collection of reptiles for the pet trade is often cited as a potential problem for threatened species, but quantitative data on the effects of this trade on wild populations are lacking. In south-eastern Australia the decline of the threatened broad-headed snake Hoplocephalus bungaroides has been blamed on habitat destruction and the collection of snakes for pets, but there was little evidence to support the latter hypothesis. During 1992-2000 we studied one of the last extant southern populations of broad-headed snakes in Morton National Park, New South Wales, where $<600$ individuals remain on an isolated plateau. Analysis of 9 years of mark-recapture data reveal that the activities of snake collectors seriously endanger the viability of this species. The study population of $H$. bungaroides was stable over 1992-1996, but declined dramatically in 1997, coincident with evidence of illegal collecting, possibly
\end{abstract}

stimulated by a government amnesty that allowed pet owners to obtain permits for illegally held reptiles. Survivorship analyses revealed that $85 \%$ of adult females disappeared from the population in 1997. There was no such effect on male survivorship, suggesting that snake collectors selectively removed adult females, which are the largest snakes in the population. Humans caused significant damage to fragile rock outcrops in three of the 9 years of the study, and a second bout of habitat disturbance in 1999 coincided with a second decline in the $H$. bungaroides population. We recommend that locked gates be placed on fire trails to protect existing populations of broad-headed snakes.

Keywords Australia, broad-headed snake, Hoplocephalus bungaroides, mark-recapture, pet trade, reptiles, Rhinoplocephalus nigrescens, small-eyed snake.

\section{Introduction}

Over the past four decades the international trade in live reptiles has been substantial, and includes a large trade in live snakes, particularly in Europe and the USA (Dodd, 1987; Luxmoore et al., 1988; Corbett, 1989; Groombridge \& Luxmoore, 1991; Adams et al., 1994; Hoover, 1998). Collection for the pet trade is often cited as a threat to wild populations of snakes (Ehrlich \& Ehrlich, 1981; Corbett, 1989; Brown, 1993), and a review of 186 species of snake believed to be threatened or in need of management listed collection for the pet trade as a threat to $23 \%$ of species (Dodd, 1987). However, there was no evidence to support this claim for any of these species (Dodd, 1987). The only detailed studies on the effects of harvesting on snake populations have

Jonathan K. Webb ${ }^{1}$ (Corresponding author), Barry W. Brook Key Centre for Tropical Wildlife Management, Northern Territory University, Darwin 0909 NT, Australia. E-mail: jonnowebb@hotmail.com

Richard Shine School of Biological Sciences, The University of Sydney, NSW 2006, Australia.

${ }^{1}$ Present address: School of Biological Sciences, The University of Sydney, NSW 2006, Australia.

Received 10 January 2001. Revision requested 29 May 2001 Accepted 27 November 2001 focused on the commercial utilization of pythons in Indonesia (Groombridge \& Luxmoore, 1991; Shine et al., 1999a, b) and rattlesnakes in the USA (Campbell et al., 1989; Reinert, 1990; Warwick et al., 1991; Brown, 1993). Although regional populations of eastern and western diamondback rattlesnakes have withstood several decades of hunting in Texas and Oklahoma (Adams et al., 1994; Fitzgerald \& Painter, 2000), populations of the timber rattlesnake in Pennsylvania and New York have declined considerably under this pressure (Martin et al., 1990; Reinert, 1990; Brown, 1993). Yet, even for these wellstudied systems, few long-term studies are available to evaluate the impacts of hunting on local snake populations (Brown, 1993; Fitzgerald \& Painter, 2000).

In south-eastern Australia, illegal collecting of snakes by reptile enthusiasts has been cited as a cause of the decline of the threatened broad-headed snake Hoplocephalus bungaroides (Burbidge \& Jenkins, 1984; Cogger et al., 1993). This small (<90 cm long), brightly coloured, nocturnal venomous snake (family Elapidae) is listed as Endangered by Australian wildlife authorities (Commonwealth Endangered Species Protection Act, 1992; Cogger et al., 1993; NSW Threatened Species Conservation Act, 1995) and Vulnerable on the 2000 IUCN Red List (Hilton-Taylor, 2000). The species is entirely restricted to sandstone rock outcrops within a 
$200 \mathrm{~km}$ radius of Sydney (Shine et al., 1998), and has declined substantially since European settlement (Krefft, 1869; Hersey, 1980). During the cooler months broadheaded snakes shelter under thin, exposed rocks on sandstone ridge tops (Webb \& Shine, 1998a). The destruction of this habitat for urban development, coupled with the collection of 'bush rocks' for landscaping urban gardens, has contributed to the snakes' widespread decline (Krefft, 1869; Hersey, 1980; Shine et al., 1998). However, 'bush rock' collection does not explain the species' decline in well-protected national parks (Shine et al., 1998). Plausibly, reptile collectors may have contributed to the decline of the broad-headed snake in national parks, particularly those near Sydney (e.g. Royal National Park).

During 1973-1997, reptile enthusiasts in New South Wales were not allowed to keep snakes unless they held a license to carry out scientific research or had held captive animals prior to 1973, whereupon they could apply to the New South Wales National Parks and Wildlife Service (NPWS) for a permit. During this period anyone caught in possession of a snake that was not licensed could be fined up to $\$ 2,500$ (Hoser, 1995). Despite these restrictions, broad-headed snakes were highly prized by reptile collectors and were collected from the wild in large numbers in the 1970s and 1980s (Hoser, 1995). Although only seven people were licensed to hold H. bungaroides in 1980 (Hersey, 1980), the number of hobbyists in Sydney who kept broad-headed snakes was much higher (Hoser, 1995).

In early 1997 NPWS drafted proposed changes to the licensing system in consultation with the Reptile Keepers Association and The Australian Herpetological Society. In April 1997 the manager of the NPWS licensing section met with reptile keepers and discussed the proposed licensing changes, which included an amnesty period for reptile keepers to obtain permits for herpetofauna in their possession. Reptile keepers were told that there would be no restriction on the number of reptiles that could be kept by an individual, and that the new licensing system could be in place as early as August 1997 (Anonymous, 1997). This early notification gave snake collectors five months to search for broad-headed snakes, at a time of year when the species is most easily located (Webb \& Shine, 1998b). On 2 October 1997 NPWS declared a 29 day amnesty, during which time collectors could obtain licenses for illegally held reptiles, including threatened species, without fear of prosecution. According to several professional herpetologists (F. Lemkert, NSW State Forests and R. Wellington, NPWS Threatened Species Unit, pers. comm.) the amnesty encouraged snake hobbyists to collect snakes from the wild and then declare them, but data to support this supposition have been lacking.
Here we use our long-term mark-recapture data from a well-known population of broad-headed snakes to investigate whether reptile collectors threaten this species. We provide data on population size and levels of disturbance by humans, and use survival analyses to investigate whether collection of snakes by humans has caused a significant decline in the population.

\section{Methods}

We studied a small, isolated population of broadheaded snakes in Morton National Park, $160 \mathrm{~km}$ south of Sydney, New South Wales (Fig. 1). At this site broadheaded snakes occur sympatrically with the small-eyed snake Rhinoplocephalus nigrescens, an abundant habitat generalist with a wide distribution in eastern Australia (Cogger, 2000). Both species of snake are nocturnal, livebearing snakes of the family Elapidae that feed mainly on lizards, but the small-eyed snake is an active searcher whereas the broad-headed snake is an ambush forager (Shine, 1983, 1984; Webb \& Shine, 1998a). At our study sites broad-headed snakes are the larger of the two species, with average adult snout-vent lengths (SVL) of $55.7 \mathrm{~cm}$ (range $48.0-66.5 \mathrm{~cm}$ ) for males and $61.5 \mathrm{~cm}$ (range $54.0-76.0 \mathrm{~cm}$ ) for females. SVL of adult smalleyed snakes are $44.8 \mathrm{~cm}$ (range 33.0-60.0 cm) for males and $39.1 \mathrm{~cm}$ (range $31.1-52.3 \mathrm{~cm}$ ) for females. In Morton National Park broad-headed snakes grow slowly and attain maturity in 5-6 years, and females reproduce once every second or third year (Webb \& Shine, 1998a; Webb et al., 2002). By contrast, small-eyed snakes grow quickly and reach maturity in 2-3 years, and a high proportion of females reproduce each year (Shine, 1984; Webb et al., 2002).

We studied both species of snake at three sites on the western side of an isolated sandstone plateau of $400 \mathrm{~m}$ elevation (Fig. 1). The sites, labelled 1, 2 and 4 for consistency with other published work, were located 1.2, 4.0 and $5.0 \mathrm{~km}$ from the northern end of the plateau and were relatively close to a fire trail (Table 1 ). The plateau is covered by open woodland forest except for the exposed western cliff tops (10-20 m wide), where small rocks have weathered from the underlying sandstone substratum. During the cooler months (May-October) both species of snake shelter under small exposed rocks or inside crevices near the cliffs (Plate 1). By late spring and summer (November-March) temperatures under exposed rocks are too hot for snakes to tolerate, and broad-headed snakes migrate to old growth forests where they shelter inside tree hollows (Webb \& Shine, 1997a, 1998a). From 1992-2000 we visited the study sites during winter and spring and searched for snakes by carefully turning over all suitable rocks (those in exposed 
Fig. 1 Location of the study sites (numbered 1,2 and 4) in Morton National Park, New South Wales. The arrow on the inset map shows the approximate location of the park in south-eastern Australia. The sandstone plateaus are accessible to four-wheel drive vehicles via fire trails.

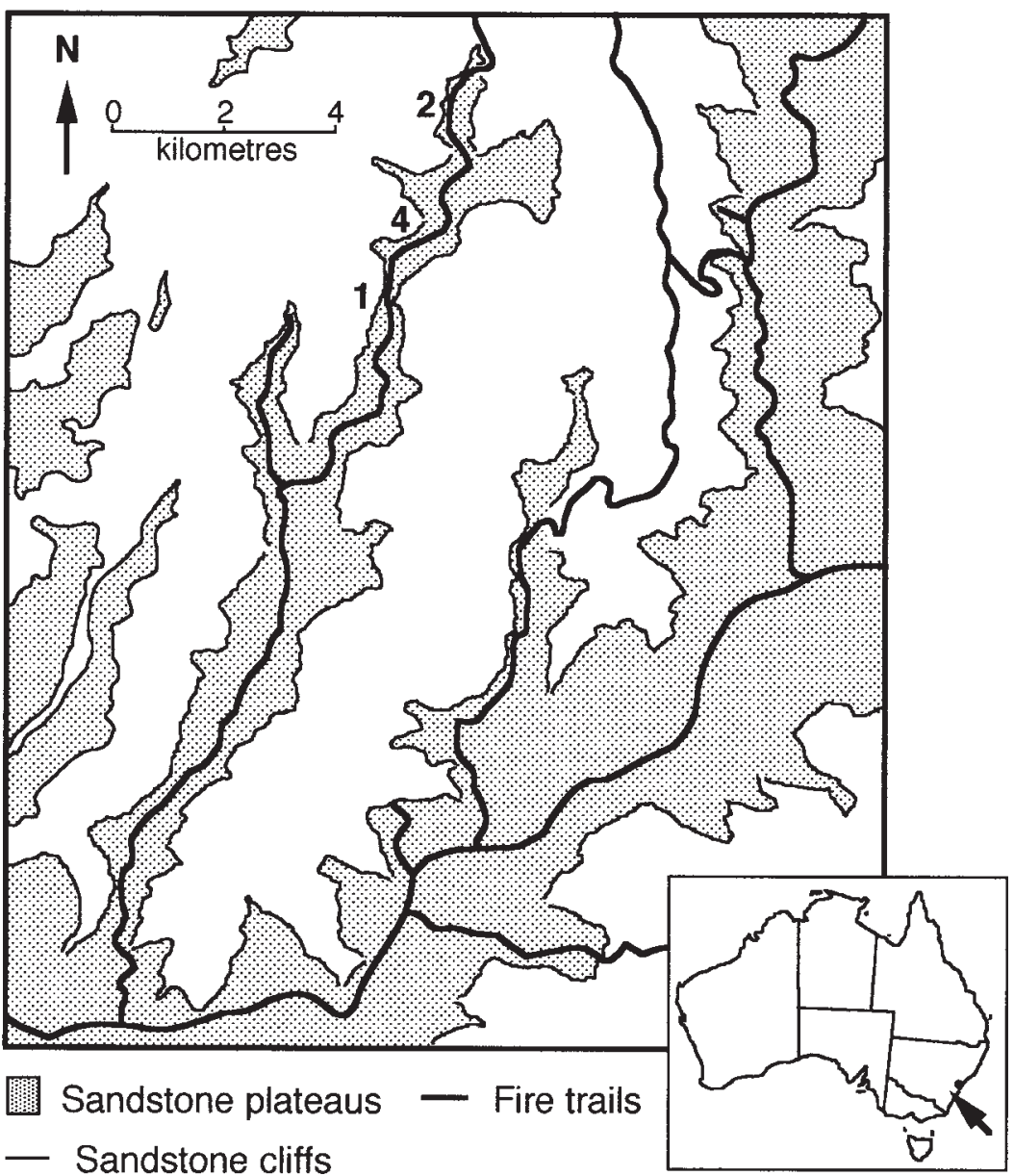

Table 1 Number of individual rocks used by broad-headed or small-eyed snakes on the three study sites, and the percentage of these rocks that were disturbed by humans during 1992-2000. The snakes did not use all rocks available to them. The distance to the road, the visibility of cliffs from the road and the total length of cliff top for each site is also shown.

\begin{tabular}{|c|c|c|c|c|c|c|c|}
\hline & \multirow[b]{2}{*}{$\begin{array}{l}\text { No. of } \\
\text { rocks }\end{array}$} & \multicolumn{3}{|c|}{$\%$ of rocks disturbed } & \multicolumn{3}{|c|}{ Physical characteristics of study sites } \\
\hline & & 1996 & 1997 & 1999 & $\begin{array}{l}\text { Distance to } \\
\operatorname{road}(\mathrm{m})\end{array}$ & $\begin{array}{l}\text { Visibility } \\
\text { of cliffs }\end{array}$ & $\begin{array}{l}\text { Length of cliff } \\
\text { top }(\mathrm{km})\end{array}$ \\
\hline Site 1 & 98 & 90 & 100 & none & 5 & Visible & 1.06 \\
\hline Site 2 & 125 & 90 & 100 & 90 & 10 & Partly visible & 1.22 \\
\hline Site 4 & 44 & none & 100 & none & 100 & Not visible & 0.72 \\
\hline
\end{tabular}

locations) and by searching inside crevices with a small torch. Small-eyed snakes use other retreat sites besides rocks and crevices, and so we also turned over any logs or sheets of bark in sunny locations within $50 \mathrm{~m}$ of the cliffs. During the first three years (August 1992November 1995) one of us (J.K.W.) searched for snakes each month during a detailed radio-telemetry study of the broad-headed snake (see Webb \& Shine, 1998a, b, for full details). From 1996 onwards 3-5 herpetologists searched for snakes on annual field trips during 28 May1 July 1996, 15-17 July 1997, 6-8 September 1998, 6-8 September 1999, 9-11 May and 1-3 September 2000.

Snakes were captured by hand and were permanently marked by injecting them with $12 \mathrm{~mm}$ passive integrated transponder (PIT) tags (Trovan ID). For each snake we measured SVL and tail length (with a ruler, to nearest $\mathrm{mm}$ ), head length and head width (with vernier calipers, to nearest $0.1 \mathrm{~mm}$ ) and mass (to nearest $0.1 \mathrm{~g}$ ), 


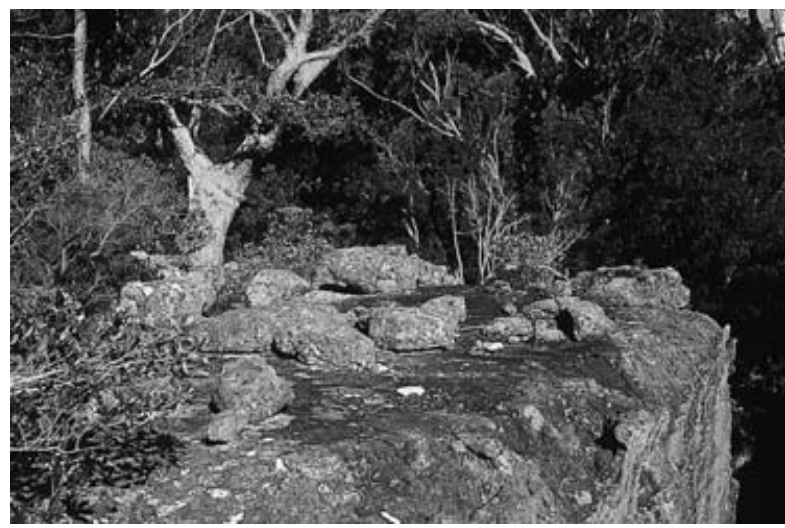

Plate 1 Sandstone cliffs on our study sites in Morton National Park. During winter and spring, broad-headed snakes and smalleyed snakes use small exposed rocks near the cliffs as thermoregulatory sites. Rocks in the adjacent forest are heavily shaded by vegetation and are unsuitable for thermoregulatory sites, and are seldom used by snakes in our study populations (Webb \& Shine, 1998b). Photograph by Jonathan Webb.

and determined sex by manual eversion of hemipenes and from tail shape (females of both species have narrow, tapering tails). At each site we estimated the percentage of rocks that had obviously been recently disturbed by humans (indicated by the remains of crushed invertebrates underneath rocks, overturned rocks, or rocks not placed back in their original position). We replaced all the rocks that had been moved back to their original position (flush with the underlying rock substratum).

\section{Statistical analyses}

We used MARK version 1.9 (White \& Burnham, 1999) to estimate demographic parameters for each species based on the mark-recapture data. The Jolly-Seber (JS) method (Pollock et al., 1990) was used to estimate population size, the Cormack-Jolly-Seber (CJS) method (Cormack, 1989) for modelling survival rates, and the Pradel method (Pradel, 1996) for estimating recruitment rates and the finite rate of increase $(\lambda)$. For survival analyses, we investigated the degree to which the data conformed to model assumptions by carrying out goodness-of-fit tests (Burnham \& Anderson, 1998). The effects of sex, time and disturbance on survival $(\varphi)$ and capture (p) probabilities were then assessed. We began with the most basic model, which assumes constant survival and recapture probabilities. In model notation (see Lebreton et al., 1992) this is represented by $\varphi$ (constant), $\mathrm{p}$ (constant). We then tested more complex models. For example, because our field trips were carried out at different times each year, and with varying numbers of herpeto- logists, we would expect recapture rates (p) to vary with year. Thus, a model with time-specific recapture rates, $\mathrm{p}$ (time), might fit the data better than a model with constant recapture rates, $\mathrm{p}$ (constant). Models were analysed using log-linear formulation, with parameters estimated through numerical maximum likelihood techniques. The Akaike Information Criterion corrected for sample size $\left(\mathrm{AIC}_{\mathrm{c}}\right)$ was used to select the most parsimonious model from a series of candidate models (Burnham \& Anderson, 1998). For each model, we calculated $\Delta \mathrm{AIC}_{\mathrm{c}}$, the difference between the $\mathrm{AIC}_{\mathrm{c}}$ for that model and the smallest $\mathrm{AIC}_{\mathrm{c}}$ among the set of models fitted, along with Akaike's weight, as recommended by Buckland et al. (1997). Akaike's weights are proportional to the normalised relative likelihoods of each model, and are used to assess the relative probability of each model being correct (Buckland et al., 1997). We chose the model with the smallest $\Delta \mathrm{AIC}_{\mathrm{c}}$ and largest Akaike's weight (Lebreton et al., 1992; Buckland et al., 1997).

We used JS population analyses to estimate the total population of broad-headed snakes on the study plateau. We measured the total length of cliffs at the study sites from enlarged aerial photographs, using a multi-scale digital plan measure (Scale Master 2, Calculated Industries, Carson City, NV, USA), and then estimated the total length of cliffs with habitat suitable for broad-headed snakes on the entire plateau using the plan measure and 1:25,000 topographic maps. We omitted cliffs on the eastern side of the plateau because these are overgrown by vegetation and do not contain broad-headed snakes (J.K. Webb, unpub. data). Searches at three randomly chosen locations on the western side of the plateau in July and August 2001 confirmed that broad-headed snakes are found along the entire western edge of the plateau.

\section{Results}

During 1992-2000 we found clear evidence that snake collectors had searched for snakes on our study sites in 1996, 1997 and 1999 (Table 1). In these years we found the fresh remains of crushed invertebrates, and occasionally geckos and skinks, underneath rocks, indicating that the rocks had been disturbed prior to our field trips. The greatest disturbance event occurred in the spring of 1997, when all of the rocks on all three study sites had been lifted (Table 1). The majority of these rocks were displaced, and a small proportion (around $10 \%$ ) had been left overturned (Plate 2) or had been pushed over cliffs (Plate 3). In 1996 a high proportion $(90 \%)$ of rocks on two of the three study sites were disturbed by humans, whereas in 1999 only one site was heavily disturbed (Table 1). In the other years there 


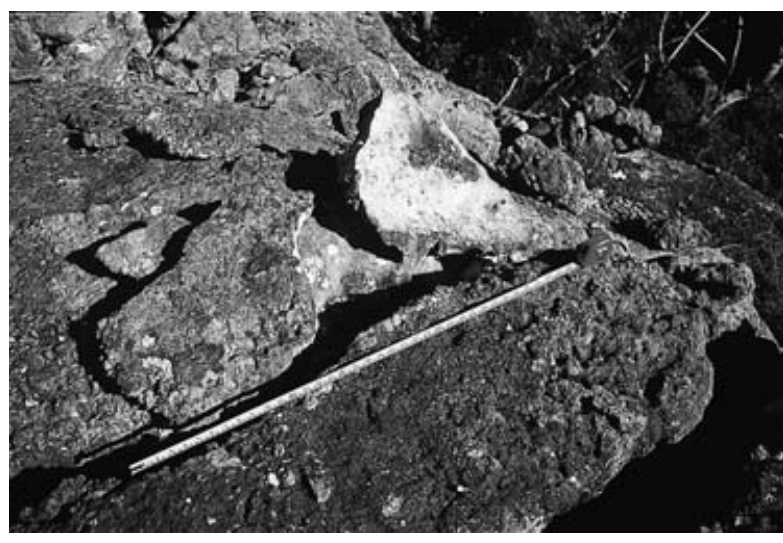

Plate 2 Human disturbance to rocks on our study sites was clearly visible from the physical displacement or breakage of rocks. Photograph by Jonathan Webb.

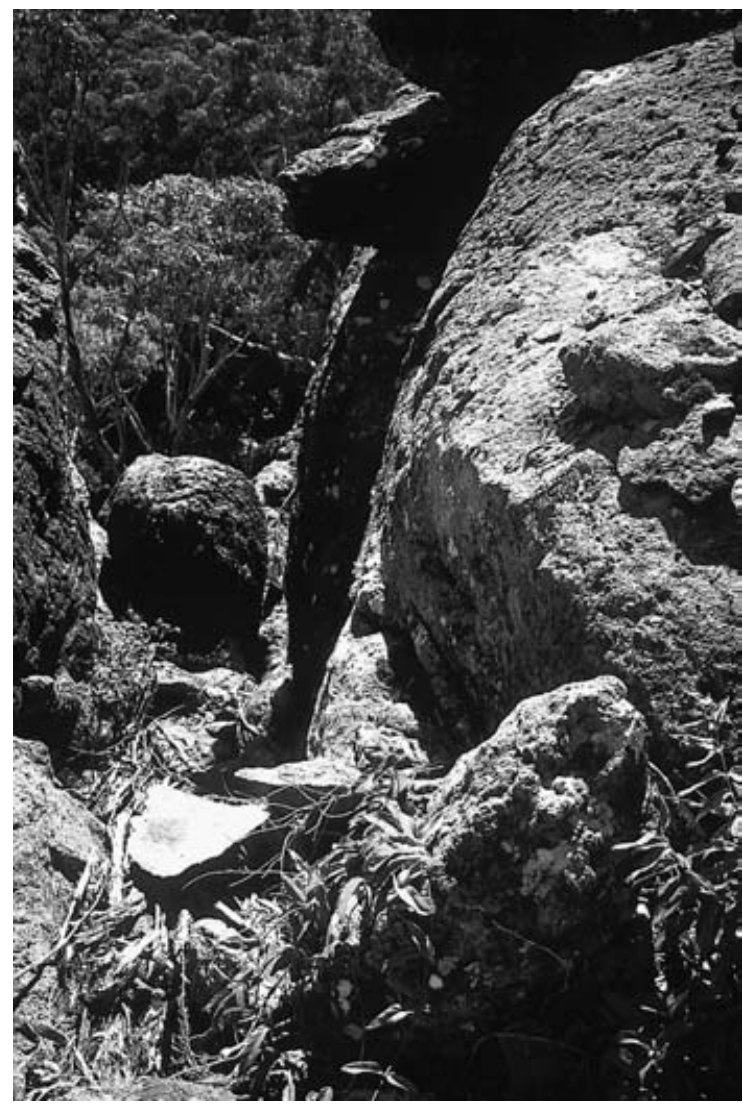

Plate 3 A scar on the rock substratum where an exposed rock has been pushed over the cliff. The displaced rock is clearly visible in the lower left hand corner of the photograph. Photograph by Jonathan Webb.

were no visible signs that natural rocks on our study sites had been disturbed. However, in August 1995 some 'artificial rocks' (concrete paving slabs) on the study sites had been overturned and several shading devices, which were placed over half the slabs, had been moved (Webb \& Shine, 2000). In this year there was no evidence of disturbance to natural rocks, so we do not consider that this disturbance was caused by snake collectors.

During 1992-2000 we captured 148 individual broadheaded snakes and 141 small-eyed snakes. Total captures and recaptures were similar for broad-headed snakes (213 captures, 65 recaptures) and small-eyed snakes (205 captures, 64 recaptures, Tables 2 and 3). Captures of broad-headed snakes were lowest in 1996 and 1997, when sites were heavily disturbed by humans (Table 2). Fewer adult broad-headed snakes were found in the three years when rocks had been disturbed (mean $=$ 4 adults) compared to other years (mean $=14.3$ adults; ANOVA $\mathrm{F}_{1,7}=11.05, P=0.01$; Table 2 ). There was no signficant effect of disturbance on the number of captures of adult small-eyed snakes (mean $=18$ adults for years with and without disturbance; Table 3). However, captures of small-eyed snakes were lowest in 1996, when humans disturbed the sites (Table 3 ). In the years with disturbance the broad-headed snakes were either removed by collectors or moved to inaccessible crevices and hence eluded capture. CJS survival analyses of the mark-recapture data allows us to differentiate between these alternative hypotheses.

\section{Survival analyses}

CJS survival analyses provided strong evidence for the selective removal of broad-headed snakes (Table 4). A bootstrap goodness of fit (GOF) test on the full CJS model showed no significant deviation (model deviance $=88.4$, mean deviance of 1000 bootstrap replicates $=69.7, P=0.092$ ) with only weak overdispersion $(c=1.27)$, which suggests that the basic assumptions of the CJS model were met (Lebreton et al., 1992). The most parsimonious survival model for the broad-headed snake was $\varphi$ (constant, F 1997) p (time); i.e. the apparent survival probability $(\varphi)$ was constant across sexes for all years, except in 1997 when female survival was significantly lower (survival $=0.15, \mathrm{SE}=0.151$ ) than in other years (mean survival $=0.80, \mathrm{SE}=0.053$ ), and capture probability $(p)$ varied with time. This model was 4.1 times better supported than an equivalent model with constant survival and time-dependent recapture rates ( $\varphi$ (constant) p (time)), in which the '1997 event' was ignored (Table 4). Thus, a model that specifically incorporated the 1997 disturbance 'event' was considerably better supported by the data than the simpler model. Finally, a model that included a decrease in both male and female survival in 1997 ( $\varphi$ (constant, M \& F 1997) $\mathrm{p}$ (time)) had 12.6 times less support than the 
Table 2 Number of captures and recaptures of broad-headed snakes at the three study sites during 1992-2000, with number of hatchlings, subadults and adults. Years in bold indicate that sites were heavily disturbed by collectors.

\begin{tabular}{|c|c|c|c|c|c|c|}
\hline \multirow[b]{2}{*}{ Year } & \multirow[b]{2}{*}{$\begin{array}{l}\text { No. of } \\
\text { captures }\end{array}$} & \multirow[b]{2}{*}{$\begin{array}{l}\text { No. of } \\
\text { recaptures }\end{array}$} & \multicolumn{2}{|l|}{ Juveniles } & \multicolumn{2}{|l|}{ Adults } \\
\hline & & & $\begin{array}{l}\text { Hatchlings } \\
(\mathrm{SVL}<30 \mathrm{~cm})\end{array}$ & $\begin{array}{l}\text { Subadults } \\
(\mathrm{SVL} \geqslant 30 \mathrm{~cm})\end{array}$ & $\begin{array}{l}\text { Males } \\
(\mathrm{SVL} \geqslant 48 \mathrm{~cm})\end{array}$ & $\begin{array}{l}\text { Females } \\
(S V L \geqslant 54 \mathrm{~cm})\end{array}$ \\
\hline 1992 & 27 & - & 8 & 6 & 8 & 5 \\
\hline 1993 & 57 & 11 & 18 & 20 & 14 & 5 \\
\hline 1994 & 31 & 14 & 6 & 5 & 14 & 6 \\
\hline 1995 & 34 & 17 & 11 & 7 & 8 & 8 \\
\hline 1996 & 8 & 4 & 2 & 2 & 2 & 2 \\
\hline 1997 & 3 & 2 & 0 & 2 & 0 & 1 \\
\hline 1998 & 21 & 5 & 4 & 7 & 7 & 3 \\
\hline 1999 & 14 & 7 & 2 & 5 & 4 & 3 \\
\hline 2000 & 18 & 5 & 4 & 6 & 5 & 3 \\
\hline
\end{tabular}

Table 3 Number of captures and recaptures of small-eyed snakes at the three study sites during 1992-2000, with number of hatchlings, subadults and adults. Years in bold indicate that sites were heavily disturbed by collectors.

\begin{tabular}{|c|c|c|c|c|c|c|}
\hline \multirow[b]{2}{*}{ Year } & \multirow[b]{2}{*}{$\begin{array}{l}\text { No. of } \\
\text { captures }\end{array}$} & \multirow[b]{2}{*}{$\begin{array}{l}\text { No. of } \\
\text { recaptures }\end{array}$} & \multicolumn{2}{|l|}{ Juveniles } & \multicolumn{2}{|l|}{ Adults } \\
\hline & & & $\begin{array}{l}\text { Hatchlings } \\
(\mathrm{SVL}<20 \mathrm{~cm})\end{array}$ & $\begin{array}{l}\text { Subadults } \\
(S V L \geqslant 20 \mathrm{~cm})\end{array}$ & $\begin{array}{l}\text { Males } \\
(\mathrm{SVL} \geqslant 33 \mathrm{~cm})\end{array}$ & $\begin{array}{l}\text { Females } \\
(\mathrm{SVL} \geqslant 31 \mathrm{~cm})\end{array}$ \\
\hline 1992 & 16 & - & 0 & 6 & 5 & $5^{*}$ \\
\hline 1993 & 16 & 2 & 0 & 3 & 7 & 6 \\
\hline 1994 & 13 & 5 & 1 & 1 & 7 & 4 \\
\hline 1995 & 14 & 6 & 0 & 1 & 8 & 5 \\
\hline 1996 & 9 & 6 & 0 & 1 & 4 & 4 \\
\hline 1997 & 30 & 4 & 5 & 1 & 9 & 15 \\
\hline 1998 & 37 & 10 & 3 & 4 & 15 & 15 \\
\hline 1999 & 26 & 14 & 1 & 3 & 10 & 12 \\
\hline 2000 & 44 & 17 & 1 & 12 & 16 & 15 \\
\hline
\end{tabular}

*One adult captured in 1992 was not sexed but, based on tail shape, was probably a female.

Table 4 Cormack-Jolly-Seber survival models describing survival $(\varphi)$ and recapture $(p)$ of broad-headed snakes at yearly intervals during 1992-2000: the most parsimonious model is shown in bold. Number of parameters $(\mathrm{N})$, Akaike's Information Criterion $\left(\mathrm{AIC}_{\mathrm{c}}\right)$, differences in $\mathrm{AIC}_{\mathrm{c}}\left(\Delta \mathrm{AIC}_{\mathrm{c}}\right)$, and Akaike's weights are given for each candidate model.

\begin{tabular}{llrrrr}
\hline $\begin{array}{l}\text { Survival } \\
(\varphi)\end{array}$ & $\begin{array}{l}\text { Recapture } \\
(\mathrm{p})\end{array}$ & $\mathrm{N}$ & $\mathrm{AIC}_{\mathrm{c}}$ & $\Delta \mathrm{AIC}_{\mathrm{c}}$ & $\begin{array}{l}\text { Akaike's } \\
\text { Weight }\end{array}$ \\
\hline Constant, F 1997* & Time & $\mathbf{1 0}$ & $\mathbf{3 5 8 . 1}$ & $\mathbf{0 . 0}$ & $\mathbf{0 . 7 0 4 8}$ \\
Constant & Time & 9 & 360.9 & 2.8 & 0.1720 \\
Sex & Time & 10 & 362.8 & 4.7 & 0.0665 \\
Constant, & Time & 10 & 363.2 & 5.1 & 0.0558 \\
$\quad$ M \& F 1997* & & & & & \\
Time & Time & 15 & 372.2 & 14.1 & 0.0006 \\
Time & Constant & 9 & 374.4 & 16.3 & 0.0002 \\
Constant & Constant & 2 & 377.0 & 18.9 & 0.0001 \\
Sex & Sex & 4 & 378.7 & 20.6 & 0.0000 \\
Sex Time & Sex Time & 30 & 385.4 & 27.3 & 0.0000 \\
\hline
\end{tabular}

${ }^{*} \mathrm{~F}=$ female; $\mathrm{M}=$ male. most parsimonious model ( $\varphi$ (constant, F 1997) $\mathrm{p}$ (time) ), and 3.1 times less support than the basic model with constant survival rates and time-specific recapture rates ( $\varphi$ (constant) $\mathrm{p}$ (time), Table 4). That is, male survival was not affected in 1997. This finding is confirmed by the mark-recapture data, which show that of 35 adults marked in the three years prior to 1997, 10 of 22 males but only 1 of 13 females 'survived' through the 1997 'event' (i.e. were captured in the three years after 1997).

The most parsimonious model for the small-eyed snake was one where survival and recapture probabilities were sex but not time specific ( $\varphi$ (sex) p (sex), Table 5). That is, survival and recapture probabilities did not vary with time, suggesting that anthropogenic disturbance did not affect survival. Mean survival $(\varphi)$ and recapture probabilities $(\mathrm{p})$ were $\varphi=0.59(\mathrm{SE}=0.07)$ and $\mathrm{p}=0.50(\mathrm{SE}=0.10)$ for females and $\varphi=0.83(\mathrm{SE}=0.06)$ and $\mathrm{p}=0.25$ ( $\mathrm{SE}=0.06)$ for males. The next best model was the most simple model with survival and recapture 
Table 5 Cormack-Jolly-Seber survival models describing survival $(\varphi)$ and recapture $(p)$ of small-eyed snakes at yearly intervals during 1992-2000: the most parsimonious model is shown in bold. Number of parameters (N), Akaike's Information Criterion ( $\mathrm{AIC}_{\mathrm{c}}$ ), differences in $\mathrm{AIC}_{\mathrm{c}}\left(\Delta \mathrm{AIC}_{\mathrm{c}}\right)$, and Akaike's weights are given for each candidate model.

\begin{tabular}{|c|c|c|c|c|c|}
\hline $\begin{array}{l}\text { Survival } \\
(\varphi)\end{array}$ & $\begin{array}{l}\text { Recapture } \\
\text { (p) }\end{array}$ & $\mathrm{N}$ & $\mathrm{AIC}_{\mathrm{c}}$ & $\Delta \mathrm{AIC}_{\mathrm{c}}$ & $\begin{array}{l}\text { Akaike's } \\
\text { Weight }\end{array}$ \\
\hline Sex & Sex & 4 & 337.2 & 0.0 & 0.5638 \\
\hline Constant & Constant & 2 & 339.9 & 2.7 & 0.1463 \\
\hline Sex & Constant & 3 & 340.1 & 2.9 & 0.1355 \\
\hline Constant, 1997 & Constant & 3 & 341.2 & 4.0 & 0.0783 \\
\hline Constant & Sex & 3 & 341.3 & 4.1 & 0.0739 \\
\hline Time & Sex & 10 & 349.3 & 12.1 & 0.0013 \\
\hline Sex & Time & 10 & 350.9 & 13.7 & 0.0006 \\
\hline Time & Time & 15 & 353.5 & 16.3 & 0.0002 \\
\hline Sex * Time & Sex $*$ Time & 30 & 374.9 & 37.7 & 0.0000 \\
\hline
\end{tabular}

probability constant throughout the study ( $\varphi$ (constant) p (constant)). This model had 3.9 times less support than the most parsimonious model, while other candidate models were not supported by the data. A bootstrap GOF test on the full CJS model showed no significant deviation (model deviance $=109.0$, mean deviance of 1,000 bootstrap replicates $=81.4, P=0.061$ ) with only weak overdispersion $(c=1.34)$, suggesting that assumptions of the CJS model were met.

\section{Responses of the snakes to disturbance}

During 1992-96, the population of broad-headed snakes remained stable, with mean population sizes of 96-101 (Fig. 2). The population suffered two marked declines in 1997 and 1999 (Fig. 2). In 1997 the population fell

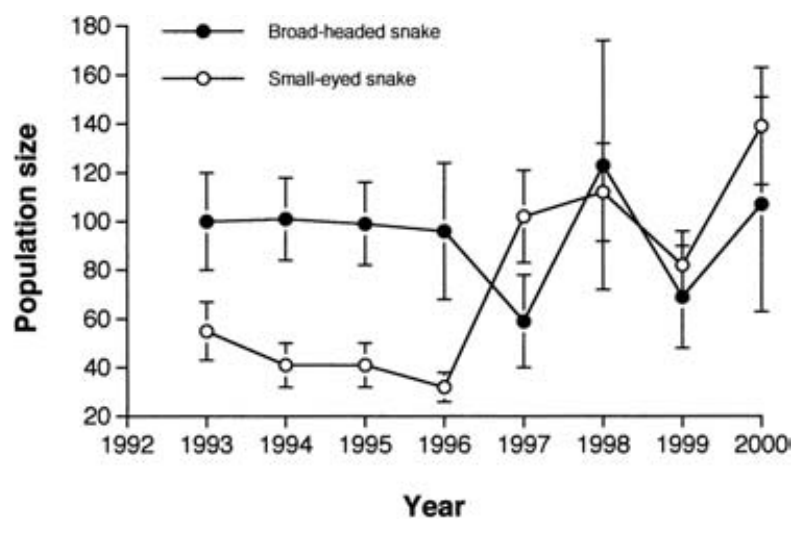

Fig. 2 Population size $( \pm S E)$ of broad-headed snakes and smalleyed snakes during 1993-2000 estimated by Jolly-Seber analysis of the mark-recapture data. from 96 to 59 individuals, but it recovered in 1998 (Fig. 2) as a result of enhanced recruitment of juveniles into the adult population. Pradel analyses showed that recruitment was 0.48 in 1998 compared to 0.21 in other years. This recruitment occurred because juveniles made up $67 \%$ of the population in 1993 (Table 2) and, based on mean growth rates for our population, many of these snakes would have reached maturity five years later in 1998. The population declined again in 1999 from 124 to 69 , and although it recovered to 107 individuals in 2000 the very large standard errors for our population estimates for all years after 1997 make it difficult to evaluate the precise magnitude of these recoveries. Captures of adult females have remained low since 1996 however (Table 2), and the current sex ratio in the population (all captures from 1997 onwards) is significantly male-biased (35 males: 14 females, $\chi^{2}=4.72$, $P=0.03)$.

From 1992-96 the population of small-eyed snakes was stable, with mean population sizes of 32-55 individuals (Fig. 2). In 1997 numbers increased dramatically from 32 to 102 individuals (Fig. 2). Analyses of recruitment rates revealed that this increase was the result of a significant increase in immigration to the study sites, most likely from adjacent forest habitat. The most parsimonious model showed that recruitment varied with time (Table 6), but was 7.8 times greater in 1997 (recruitment $=2.46, \mathrm{SE}=0.75$ ) than the average of all other years (mean recruitment rate $=0.28, \mathrm{SE}=0.06$ ).

\section{Number of broad-headed snakes on the study plateau}

No previous population estimates are available for the broad-headed snake (Cogger et al., 1993). We estimate that the mean density of broad-headed snakes on the $3.0 \mathrm{~km}$ of ridge top that made up the study sites was 33.0 snakes per $\mathrm{km}$ (based on the mean population size of 99 snakes between 1992-1995). Using an estimate of $18.0 \mathrm{~km}$ for the total length of habitat suitable for broad-headed snakes on the study plateau we calculate that $<600$ individuals remain on the plateau (mean population size $=594$ snakes, $95 \%$ confidence intervals $=$ 389-808 individuals). Recent surveys (July-August 2001) revealed that snake collectors have recently disturbed $>90 \%$ of the natural rocks on the western cliffs in the southern and middle regions of the plateau (J.K. Webb, unpubl. data).

\section{Snakes declared during the wildlife amnesty}

Snake keepers declared 814 venomous snakes of 39 species in the family Elapidae to NPWS during the 1997 
Table 6 Pradel recruitment models describing the survival $(\varphi)$, recapture $(p)$ and recruitment $(f)$ of broad-headed snakes and small-eyed snakes at yearly intervals during 1992-2000, with the number of parameters (N), Akaike's Information Criterion $\left(\right.$ AIC $\left._{c}\right)$, differences in AIC $c$ $\left(\Delta \mathrm{AIC}_{\mathrm{c}}\right)$, and Akaike's weights for candidate models. The most parsimonious model for each species of snake is shown in bold.

\begin{tabular}{|c|c|c|c|c|c|c|}
\hline Survival $(\varphi)$ & Recapture (p) & Recruitment (f) & $\mathrm{N}$ & $\mathrm{AIC}_{\mathrm{c}}$ & $\Delta \mathrm{AIC}_{\mathrm{c}}$ & Akaike's Weight \\
\hline \multicolumn{7}{|c|}{ Broad-headed snakes } \\
\hline Constant & Time & Constant & 11 & 879.4 & 0.0 & 0.6720 \\
\hline Constant & Time & Sex & 12 & 881.0 & 1.6 & 0.2984 \\
\hline Constant & Time & Time & 15 & 885.6 & 6.2 & 0.0297 \\
\hline \multicolumn{7}{|c|}{ Small-eyed snakes } \\
\hline Sex & Sex & Time & 10 & 912.8 & 0.0 & 0.8404 \\
\hline Sex & Sex & Constant, 1997 & 6 & 916.1 & 3.3 & 0.1580 \\
\hline Sex & Sex & Sex & 6 & 925.4 & 12.6 & 0.0015 \\
\hline Sex & Sex & Constant & 5 & 932.4 & 19.4 & 0.0001 \\
\hline
\end{tabular}

wildlife amnesty. We ranked the top 15 species of elapid snakes according to the number of permits issued to private individuals to hold that particular species (Table 7). Common species with broad geographic distributions were among the most popular species declared by snake hobbyists. However, two threatened species, the broad-headed snake and Stephen's banded snake, were ranked at 8 and 14 respectively in this list (Table 7). Seven licences were also given to individuals to keep three species, the white-crowned snake Cacophis harriettae, the pale headed snake Hoplocephalus bitorquatus and the whip hooded snake Suta flagellum, that are listed as Vulnerable on the NSW Threatened Species Conservation Act 1995.

\section{Discussion}

Evaluating whether collection threatens wild populations of broad-headed snakes is important for designing adequate conservation and management programmes (e.g. Caughley \& Gunn, 1995). Our data show that reptile collectors continue to cause widespread disturbance to fragile rock outcrops within Morton National Park. Anthropogenic disturbance to natural rocks occurred in three of the 9 years of this study, and coincided with decreases in the population of the broad-headed snake (Fig. 2). Disturbance to rocks, without any removal of broad-headed snakes, could have decreased our chances of finding snakes. However, this is unlikely because

Table 7 The 15 most common species of the 39 venomous snakes (family Elapidae) declared by private reptile keepers to New South Wales National Parks and Wildlife Service (NPWS) during the 1997 wildlife amnesty. A total of 423 licenses were issued to individuals to hold 814 venomous snakes (courtesy of NPWS). * listed as Vulnerable on the IUCN Red List (Hilton-Taylor, 2000). † listed as Vulnerable on the NSW Threatened Species Conservation Act 1995. NPWS staff did not view snakes when licenses were issued.

\begin{tabular}{|c|c|c|c|}
\hline Species & Common name & Number of licenses & Number of snakes \\
\hline Pseudechis porphyriacus & Red-bellied black snake & 84 & 130 \\
\hline Acanthophis antarcticus & Southern death adder & 48 & 115 \\
\hline Notechis scutatus & Common tiger snake & 32 & 71 \\
\hline Hemiaspis signata & Marsh snake & 28 & 51 \\
\hline Pseudonaja textilis & Eastern brown snake & 26 & 53 \\
\hline Demansia psammophis & Yellow-faced whipsnake & 20 & 42 \\
\hline Pseudechis colletti & Collett's snake & 18 & 38 \\
\hline Hoplocephalus bungaroides* & Broad-headed snake & 15 & 30 \\
\hline Pseudechis guttatus & Spotted black snake & 15 & 26 \\
\hline Rhinoplocephalus nigrescens & Small-eyed snake & 14 & 28 \\
\hline Pseudechis australis & Mulga snake & 13 & 19 \\
\hline Austrelaps ramsayi & Highlands copperhead & 12 & 26 \\
\hline Oxyuranus microlepidotus & Fierce snake & 9 & 23 \\
\hline Hoplocephalus stephensiit & Stephen's banded snake & 8 & 14 \\
\hline Notechis ater & Black tiger snake & 7 & 15 \\
\hline
\end{tabular}


although we only found three broad-headed snakes in 1997, we found 30 small-eyed snakes. Indeed, the population of small-eyed snakes actually increased in 1997 as a result of increased immigration to the study sites. Moreover, captures of small-eyed snakes were similar in years with and without disturbance (Table 3). These comparative data suggest that reptile collectors removed the brightly coloured broad-headed snakes, but not the drab-coloured small-eyed snakes, which are less desirable.

Disturbance to natural rocks was greatest in 1997 when the NPWS amnesty was declared. Although the amnesty may not have been responsible for the removal of broad-headed snakes (see below), it may have exacerbated the situation. Several aspects of the NPWS amnesty were poorly designed. Threatened species were not excluded from the amnesty, there were no restrictions on the number of specimens that could be registered, and 5 months notification was given to reptile keeping clubs that an amnesty would be declared. The amnesty period was one month long, which even without forewarning gave people enough time to collect rare species from the wild. In addition, the amnesty was held in October when many reptiles in south-eastern Australia, including the broad-headed snake, can be easily collected from under rocks and other cover items. Future amnesties could be improved by not forewarning the public that an amnesty will be held, excluding threatened species from the amnesty, holding the amnesty over summer when dormant reptiles cannot be collected easily, and restricting the amnesty to a shorter period of time, e.g. 1 week rather than 1 month.

Irrespective of whether collection was linked to the amnesty, our results show that reptile collectors can seriously affect populations of broad-headed snakes. Cormack-Jolly-Seber survival analyses revealed that $85 \%$ of female broad-headed snakes disappeared from the population in 1997, with the total population declining by $39 \%$ in this year. The disappearance of female broadheaded snakes is unlikely to be the result of natural causes linked to reproduction because there were few births in the population in 1996 (Table 2). The most plausible explanation is that reptile collectors removed the largest snakes, which are females. The high degree of human disturbance to our study sites in 1996, 1997 and 1999, and most recently at one of our sites in August 2001 (J.K. Webb, unpub. data), suggests that there may be a large-scale illegal trade in broad-headed snakes in Australia and/or elsewhere. Notably, heavy disturbance to our study sites occurred soon after the exact location of the sites was published in two international reptile magazines and on the internet (Hoser, 1995). This is similar to a situation in the USA where rattlesnake populations were decimated by collectors after the locations of several large communal dens were published in the popular literature (Brown, 1993).

The sustained removal of a high proportion of adult broad-headed snakes may be detrimental to the future viability of this population. Broad-headed snakes grow slowly, and females produce small clutches of offspring (mean $=5.0$ ) every second or third year (Webb \& Shine, 1998a). Adults show extreme site-fidelity, and although they move long distances to old growth forests in summer, they return to the same rock outcrops each winter and spring (Webb \& Shine, 1997a). Juvenile broad-headed snakes are poor dispersers, and move $<600 \mathrm{~m}$ from their birth sites (Webb \& Shine, 1997b). Collectively, these life history traits make long-lived species like the broad-headed snake vulnerable to increases in adult mortality (Miller \& Botkin, 1974; Crouse et al., 1987; Brooks et al., 1991; Congdon et al., 1993; Webb et al., 2002). More importantly, population viability models for species with life history traits similar to the broad-headed snake show that the annual removal of even relatively low proportions (0.02-0.07) of adults can drive populations to extinction (Miller \& Botkin, 1974; Seigel \& Sheil, 1999).

Populations of both species of snake were stable prior to 1996, but fluctuated greatly thereafter. Previous studies on exploited lizard and snake populations show that high levels of variability are inherent in these systems, which makes it difficult to distinguish trends and to determine whether they are natural fluctuations or the result of harvesting (Fitzgerald, 1994; Fitzgerald \& Painter, 2000). This is true for our study system also. For example, the large standard errors associated with our population estimates from 1996 onwards make it difficult to determine the magnitude of the 'recovery' of the broad-headed snake population in 1998 and 2000. Similarly, we cannot say for certain whether the decline of both species in 1999 was a natural fluctuation or the result of collection (Fig. 2), although data on the disturbance of rocks would suggest the latter. Longer-term data sets will be needed to assess the effects of the collection of snakes on the future viability of the study population (e.g., Fitzgerald, 1994; Fitzgerald \& Painter, 2000).

The persistence of broad-headed snakes on the study plateau will depend on the population size, immigration from other plateaus, stochastic environmental events such as wildfires, and the effects of harvesting (Caughley \& Gunn, 1995). The small size of this population $(<600)$ means it will face the risks associated with demographic and environmental stochasticity and loss of genetic variation (Soulé, 1996). The geographic isolation of the study plateau, and the absence of broad-headed snakes on plateaus to the west (J.K. Webb, unpub. data), coupled with the species' extreme side-fidelity and poor dispersal, mitigates against immigration from other popu- 
lations. These factors may increase the risk of inbreeding depression, which is characterised by poor growth and low fertility, fecundity and offspring viability (Charlesworth \& Charlesworth, 1987; Madsen et al., 1996). Notably, females from our study population produce a high proportion of still-born young (Shine \& Fitzgerald, 1989; Webb \& Shine, 1998b), which may suggest that inbreeding is already occurring (Madsen et al., 1996). However, in the short-term, the greatest threat to the population is the illegal removal of rocks and the collection of snakes. Both of these threats can be minimised relatively easily, but will require wildlife authorities to act soon.

\section{Management recommendations}

We suggest that locked gates be placed at either end of three fire trails that traverse ridge tops adjacent to Morton National Park, where the broad-headed snake is currently found. Locked gates would protect the species and its habitat by preventing reptile collectors and bush rock collectors from driving to rock outcrops. A system of locked gates is currently used in water catchment areas and national parks close to Sydney (e.g. Ku-ring-gai Chase and Royal National Park) and has protected sandstone ridge tops from rock thieves. However, recent discussions with NPWS suggest that the placement of locked gates on fire trails in our study area will be difficult because the fire trails are on Crown Land that is currently under land claim (M. Saxon, pers. comm.). The introduction of locked gates will require cooperation between the NPWS, Shoalhaven City Council and other government authorities. The fire trails in question are also extremely popular with recreational drivers, who may object to a locked gate system, although a permit system could be introduced to allow responsible four-wheel drive clubs to obtain access to fire trails during the summer months (NovemberMarch) when broad-headed snakes do not use rocks as shelter sites (Webb \& Shine, 1998b). A locked gate and permit system currently operates on the Tianjara fire trail in Morton National Park, and could serve as a model for managing other fire trails.

\section{Acknowledgements}

We thank the following people for their assistance in the field over the past 8 years. They are, in alphabetical order: Paul Doughty, Rebecca Drury, Mark Gardener, Pavel German, Jo Hines, Michael Kearney, Scott Keogh, Jenny Koenig, Thomas Madsen, Mathew McCloskey, Dave O'Conner, Mats Olsson, Mark O'Shea, Myfanwy
Runcie, Kylie Russell, Sarah Smith, Adam Stow, Elisabeth Tasker, Mike Thompson, Geordie Torr, Raoul Van Damme, James Walker, George White, Pat Whittaker and Marianna Ypma. We especially thank Max Pincombe for allowing us to stay in his field hut. Hal Cogger and two anonymous reviewers provided critical comments and suggestions that greatly improved an earlier version of the manuscript. The project was supported by a Northern Territory University Research Support Grant and Australian Research Council Postdoctoral Fellowship to Jonathan Webb, and an Australian Research Council Special Investigator Award to Richard Shine. Yorkshire Television provided airfares and car hire that enabled Jonathan Webb to carry out the fieldwork in 1999. The New South Wales National Parks and Wildlife Service provided logistical support from 1992-1996 and allowed us to continue our long-term field monitoring (license number A2686 to Jonathan Webb). The fieldwork was carried out in accordance with The University of Sydney Animal Ethics and Experiments Committee guidelines.

\section{References}

Adams, C.E., Thomas, J.K., Strandel, K.J. \& Jester, J.L. (1994) Texas rattlesnake roundups: implications of unregulated commercial use of wildlife. Wildlife Society Bulletin, 22, 324-330.

Anonymous (1997) Keepers licenses for N.S.W. herpetologists may no longer be a fantasy! The Hawkesbury Herpetologist, 12, 40-41.

Brooks, R.J., Brown, G.P. \& Galbrath, D.A. (1991) Effects of a sudden increase in natural mortality of adults on a population of the common snapping turtle (Chelydra serpentina). Canadian Journal of Zoology, 69, 1314-1320.

Brown, W.S. (1993) Biology, status and management of the timber rattlesnake (Crotalus horridus): a guide for conservation. SSAR Herpetological Circular, 22, 1-78.

Buckland, S.T., Burnham, K.P. \& Augustin, N.H. (1997) Model selection: an integral part of inference. Biometrics, 53, 603-618.

Burbidge, A.A. \& Jenkins, R.W.G. (1984) Endangered Vertebrates of Australia and its Island Territories. Report of the working group on endangered fauna of the standing committee of the council of nature conservation. Australian National Parks and Wildlife Service, Canberra.

Burnham, K.P. \& Anderson, D.R. (1998) Model Selection and Inference. Springer-Verlag, Berlin.

Campbell, J.A., Formanowicz, D.R. \& Brodie, E.D. Jr (1989) Potential impact of rattlesnake roundups on natural populations. Texas Journal of Science, 41, 301-317.

Caughley, G. \& Gunn, A. (1995) Conservation Biology in Theory and Practice. Blackwell Science, Oxford.

Charlesworth, D. \& Charlesworth, B. (1987) Inbreeding depression and its evolutionary consequences. Annual Review of Ecology and Systematics, 18, 237-268.

Cogger, H.G. (2000) Reptiles and Amphibians of Australia. Sixth Edition. Reed Books, Sydney. 
Cogger, H.G., Cameron, E.E., Sadlier, R.A. \& Eggler, P. (1993) The Action Plan for Australian Reptiles. Australian Nature Conservation Agency, Canberra.

Congdon, J.D., Dunham, A.E. \& Van Loben Sels, R.C. (1993) Delayed sexual maturity and demographics of Blanding's turtles (Emydoidea blandingii): implications for conservation and management of long-lived organisms. Conservation Biology, 7, 826-833.

Corbett, K. (1989) The Conservation of European Reptiles and Amphibians. The Conservation Committee of the Societas Europaea Herpetolgica, IUCN/SSC European Reptile and Amphibian Specialist Group. Christopher Helm, London.

Cormack, R.M. (1989) Log-linear models for capture-recapture. Biometrics, 45, 395-414.

Crouse, D.T., Crowder, L.B. \& Caswell, H. (1987) A stage-based population model for loggerhead sea turtles and implications for survival. Ecology, 68, 1412-1423.

Dodd, C.K. (1987) Status, conservation and management. In Snakes: Ecology and Evolutionary Biology (eds R.A. Seigel, J.T. Collins \& S.S. Novak), pp. 478-513. McGraw-Hill, New York.

Ehrlich, P. \& Ehrlich, A. (1981) Extinction: the Causes and Consequences of the Disappearance of Species. Random House, New York.

Fitzgerald, L.A. (1994) The interplay between life history and environmental stochasticity: implications for management of exploited lizard populations. American Zoologist, 34, 371-381.

Fitzgerald, L.A. \& Painter, C.W. (2000) Rattlesnake commercialization: long-term trends, issues, and implications for conservation. Wildlife Society Bulletin, 28, 235-253.

Groombridge, B. \& Luxmoore, R. (1991) Pythons in southeast Asia. A review of distribution, status and trade in three selected species. Report to CITES Secretariat, Laussane, Switzerland.

Hersey, F. (1980) Broad-headed snake Hoplocephalus bungaroides. In Parks and Wildife: Endangered Animals of New South Wales (ed. C. Haegl), pp. 38-40. New South Wales National Parks and Wildlife Service, Sydney.

Hilton-Taylor, C. (compiler) (2000) 2000 IUCN Red List of Threatened Animals. IUCN, Gland, Switzerland and Cambridge, UK.

Hoover, C. (1998) The U.S. Role in the International Live Reptile Trade: Amazon Tree Boas to Zululand Dwarf Chameleons. Traffic North America, Washington.

Hoser, R. (1995) The Australian broad-headed snake Hoplocephalus bungaroides. The Reptilian Magazine, 3, 15-27.

Krefft, G. (1869) The Snakes of Australia: an Illustrated and Descriptive Catalogue of all the Known Species. Thomas Richards, Government Printer, Sydney.

Lebreton, J.D., Burnham, K.P., Clobert, J. \& Anderson, D.R. (1992) Modeling survival and testing biological hypotheses using marked animals: case studies and recent advances. Ecological Monographs, 62, 67-118.

Luxmoore, R., Groombridge, B. \& Broad, S. (1988) Significant Trade in Wildlife: a Review of Selected Species in CITES Appendix II. Vol. 2. Reptiles and Invertebrates. IUCN, Cambridge, UK
Madsen, T., Stille, B. \& Shine, R. (1996) Inbreeding depression in an isolated population of adders Vipera berus. Biological Conservation, 75, 113-118.

Martin, W.H., Smith, W.H., Harwig, S.H., Magram, R.O. \& Stechert, R. (1990) Distribution and Status of the Timber Rattlesnake (Crotalus horridus) in Pennsylvania. Unpublished report to the Carnegie Museum of Natural History and the Pennsylvania Fish Commission.

Miller, R.S. \& Botkin, D.B. (1974) Endangered species: models and predictions. American Scientist, 62, 172-181.

Pollock, K.H., Nichols, J.D., Brownie, C. \& Hines, J.E. (1990) Statistical inference for capture-recapture experiments. Wildlife Monographs, 107. The Wildlife Society, Behesda, MD.

Pradel, R. (1996) Utilisation of capture-mark-recapture for the study of recruitment and population growth rate. Biometrics, 52, 703-709.

Reinert, H.K. (1990) A profile and impact assessment of organised rattlesnake hunts in Pennsylvania. Journal of Pennsylvania Academy of Science, 64, 136-144.

Seigel, R.A. \& Sheil, C.A. (1999) Population viability analysis: applications for the conservation of massasaugas. In Second International Symposium and Workshop on the Conservation of the Eastern Massasauga Rattlesnake, Sistrurus catenatus catenatus: Population and Habitat Management Issues in Urban, Bog, Prairie and Forested Ecosystems (eds B. Johnson \& M. Wright), pp.17-22. Toronto Zoo, Toronto, Ontario.

Shine, R. (1983) Arboreality in snakes: ecology of the Australian elapid genus Hoplocephalus. Copeia, 1983, 198-205.

Shine, R. (1984) Reproductive biology and food habits of the Australian elapid snakes of the genus Cryptophis. Journal of Herpetology, 18, 33-39.

Shine, R. \& Fitzgerald, M. (1989) Conservation and reproduction of an endangered species: the broad-headed snake, Hoplocephalus bungaroides (Elapidae). Australian Journal of Zoology, 25, 65-67.

Shine, R., Webb, J.K., Fitzgerald, M. \& Sumner, J. (1998) The impact of bush-rock removal on an endangered snake species, Hoplocephalus bungaroides. Wildlife Research, 25, 285-295.

Shine, R., Ambariyanto, Harlow, P.S. \& Mumpuni (1999a) Ecological attributes of two commercially harvested python species in Northern Sumatra. Journal of Herpetology, 33, 249-257.

Shine, R., Ambariyanto, Harlow, P.S. \& Mumpuni (1999b) Reticulated pythons in Sumatra: biology, harvesting and sustainability. Biological Conservation, 87, 349-357.

Soulé, M.E. (1996) Viable Populations for Conservation. Cambridge University Press, Cambridge, UK.

Warwick, C., Steedman, C. \& Holford, T. (1991) Rattlesnake collection drives - their implications for species and environmental conservation. Oryx , 25, 39-44.

Webb, J.K. \& Shine, R. (1997a) Out on a limb: conservation implications of tree-hollow use by a threatened snake species (Hoplocephalus bungaroides: Serpentes, Elapidae). Biological Conservation, 81, 21-33.

Webb, J.K. \& Shine, R. (1997b) A field study of spatial ecology and movements of a threatened snake species, Hoplocephalus bungaroides. Biological Conservation, 82, 203-217. 
Webb, J.K. \& Shine, R. (1998a) Ecological characteristics of a threatened snake species, Hoplocephalus bungaroides (Serpentes, Elapidae). Animal Conservation, 1, 185-193.

Webb, J.K. \& Shine, R. (1998b) Using thermal ecology to predict retreat-site selection by an endangered snake species. Biological Conservation, 86, 233-242.

Webb, J.K. \& Shine, R. (2000) Paving the way for habitat restoration: can artificial rocks restore degraded habitats of endangered species? Biological Conservation, 92, 93-99.

Webb, J.K., Brook, B.W. \& Shine, R. (2002) What makes a species vulnerable to extinction? Comparative life history traits of two sympatric snakes. Ecological Research, 17, in press.

White, G.C. \& Burnham, K.P. (1999) Program MARK: survival estimation from populations of marked animals. Bird Study, 46S, 120-138.

\section{Biographical sketches}

Jonathan Webb received his $\mathrm{PhD}$ from the University of Sydney in 1997. Recently he has worked on a number of projects in the wet-dry tropics, including the ecophysiology of viviparous reptiles, the impact of cane toads on varanid lizard populations, and the sustainable use of mangrove monitors by Aboriginal Australians. Dr Webb was recently awarded the Margaret Middleton Award for Conservation from the Australian Academy of Science for his research on the broad-headed snake. He is currently based at the University of Sydney and is studying competition between sympatric snakes.

Barry Brook, a lecturer at the Northern Territory University, Darwin, is a conservation biologist with interests in biotic extinctions (past and present), population modeling and viability analyses for threatened flora and fauna, wildlife management and palaeoecology.

Richard Shine is a Professor in Evolutionary Biology at the University of Sydney and has carried out extensive research on snake biology. He has conducted conservation related research on the commercial exploitation of pythons in Sumatra, and on the ecology of reptiles in urban environments. 